Warm up

\title{
Research realpolitik
}

\section{P McCrory}

$\mathrm{H}$ aving recently returned from a series of meetings around the world I am amazed at the extreme variability in clinical sports medicine and research that exists in different countries. I am struck by many similar complaints by geographically disparate clinicians. They are all either "too busy" to write something for the journal or else "just about" to write. It seems that this author's pre-launch phase is a phenomenon not limited to sports medicine however the need in this discipline is urgent.

This is also something that is seen first hand in the journal. Manuscript submissions from Britain are declining while those from Australia, Europe, and Asia are increasing. This is particularly noticeable in clinical papers. While it may be easy to blame a new editor for this revolution, closer inspection shows that this change has been happening inexorably over a number of years. The journal hasn't changed, the world has!

There are also a number of big picture issues that deserve discussion. Our specialty suffers from a number of credibility issues that are critical. As various sports medicine colleges and organisations worldwide gather impetus to achieve full specialist recognition, we are all too often regarded by our collegiate peers as being part of a Cinderella specialty. Certainly we lack the historical roots that many Colleges take for granted yet we offer something that is new, important, and distinctly different.

To survive the blowtorch to our collective bellies, we desperately need an evidence base upon which we can develop our guidelines and management pathways. Without this we are lost. Remember the old adage that the plural of anecdotes is not data. How can we develop this evidence base without the involvement of our clinical brethren? It seems our sports science colleagues take much of this for granted. Largely academically based, they have long had the "publish or perish" imperative. In many countries, the sports science leads they way. If only the clinicians would follow.

What then are the barriers for clinicians to publish? I suspect is cultural or political in the broadest sense of those words. Research groups around the world that foster a philosophy of publishing quality research continue to build respect and influence at an international level. This is somewhat limited by the "critical mass" phenomenon. It takes time to build up to a level that sustains itself but when that happens the growth tends to be exponential. The ratelimiting step seems to be leadership. The right person can inspire others to great deeds whereas the wrong person generates mediocrity. The selection of leaders for such groups should be based more on academic merit and/or personal ability than on any "old boy" network.

For solo or small groups where critical mass is difficult or nigh on impossible to achieve, life is tough. Thrown back on limited resources one's goals have to start small. Having said this, it is a salutary exercise to read the recent obituary of Dr Will Pickles published in the Journal of the Royal Society of Medicine $(2001 ; 94: 536-40)$. As a busy country GP, this man single handedly discovered or characterised many common illnesses simply by good documentation and an inquiring mind. Yet when I hear clinicians' talk of needing "protected research time" from their employers to be able to write whatever magnum opus is within them I shudder. Time is not the answer for an excess of academic inertia.

Other new developments may also influence this culture. The privatisation of sports medicine clinics may seem an interesting step but if it comes at the price of stifling research and reducing publication output, is it worth it? This development could be a potential boon to researchers with computerised databases of diagnoses allowing large scale or even multicentre studies to occur. It needs leadership in order to convince health bureaucrats and bean counters that research will actually improve quality and may have the positive spin off of good publicity. Heaven knows some of these health bodies could do with good news from time to time!

What about trainees? Clearly to foster a culture of research and publication amongst registrars is important. These are the people who hopefully will continue these habits long into their careers. In Australia, it is a requirement of the College training programme that all registrars must have at least one paper published in a peer reviewed journal prior to being admitted to Fellowship. Simple but effective. To do this on a wider scale requires some academic mentoring and access to research infrastructure, which is largely the province of academia rather than privatised or corporatised medicine. Still with an administrative body behind the initiative it can easily be achieved. That body may be a medical one or a sports medicine umbrella organisation. The issue is the culture not the name. Unfortunately when the focus is on the development of splinter groups not the broader picture, research gets lost in the mix.

In part, some of the difficulty may relate to the need to demystify the publication process be it the writing, submission, or publication of a journal article. Reading the various journals could be a starting point for some clinicians. There is no point having "a dozen cases ready to write up" if nothing happens. Although most people think of publishing a paper as stroking their ego, the process can be a learning one for the author involved. If someone reads it and gets the message or changes their management appropriately then that is a bonus.

In sports medicine, we have a clear choice. Publish or perish. We have reached a level of medical sophistication where to go upward we need to have solid foundations of evidence beneath us. As they say in the Olympics; Citius, Altius, Fortius

Br J Sports Med 2002;36:1 


\section{Boxing and the brain}

\section{P McCrory}

\section{Revisiting chronic traumatic encephalopathy}

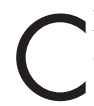
hronic traumatic brain injury or chronic traumatic encephalopathy (CTE) is considered by some authorities to be the most serious health problem in modern day boxing. ${ }^{1}$ The condition is often referred to by a number of names in the medical and non-medical literature including dementia pugilistica and "punch drunk" syndrome.

Whilst there exists great controversy regarding the ethics of boxing, one of the key medical issues is the risk of a boxer developing CTE either during or after his boxing career. Recent evidence suggests that exposure to boxing alone is insufficient to cause this condition.

It is believed that CTE represents the cumulative long term neurological consequences of repetitive concussive and sub concussive blows to the head. ${ }^{1-4}$ CTE ismorecommoninprofessionalratherthan amateur boxers, however, CTE has been documented in other sports such as AmericanFootball,icehockey,rugby, horse racing, and soccer. ${ }^{5-7}$

CTE is clinically characterised by a combination of speech and gait disturbance, pyramidal tract dysfunction, memory impairment, extrapyramidal features, behavior or personality changes, and psychiatric disease..$^{1-38}$ In the early stages of this condition, the symptoms are transient and reversible, however, in the later stages they are progressive.Theneurology ofCTEincludes characteristic neuropathological features of cerebral atrophy, septal fenestration, cerebellar tonsillar scarring, cavum septum pellucidum, loss of pigmented cells, and prominent neurofibrillary tangles. ${ }^{7}$

It is salient to review the original paper discussing the neuropathology of CTE. Although individual case reports had been published of boxers with chronic dementing illnesses, the seminal paper discussing the association of neuropathological findings in boxers was published by the English pathologist,
John Corsellis. ${ }^{7}$ He studied the brains of 15 retired boxers and retrospectively studied their fight histories. While a number of characteristic changes were noted in these brains, it is the boxers' histories that deserve specific note. Of the fighters studied, their exposure to boxing ranged between 300 and 700 bouts in the course of their careers. This was in addition to sparring and other fight training that would have occurred.

The issue then that needs consideration is that in this day and age we would seldom see a fighter with such a record. Even the top professionals report fight careers of 30-50 fights before retirement, an order of magnitude less than that described in Corsellis' landmark study.

Recent research in boxers has also suggested that CTE in boxers may be associated with a particular genetic predisposition. The apolipoprotein E $\epsilon-4$ gene (ApoE), a susceptibility gene for late onset familial and sporadic Alzheimer's disease, may be associated with an increased risk of CTE in boxers. ${ }^{169}$

In a non-boxing population, ApoE polymorphism was significantly associated with death and adverse outcomes following acute traumatic brain injury as seen in a neurosurgical unit. ${ }^{10}$ In a recent prospective study, ApoE genotypes were tested for their ability to predict days of unconsciousness and functional outcome after six months. ${ }^{11}$ There was a strongassociation demonstrated between the ApoE allele and poor clinical outcome.

Furthermore, ApoE deficient (knockout) mice have been shown to have memory deficits, neurochemical changes, and diminished recovery from closed head injury when compared to controls. ${ }^{12}$ It is suggested that ApoE plays an important role in both neuronal repair and antioxidant activity resulting in ApoE knockout mice exhibiting an impaired ability to recover from closed head injury.

How then does this help the debate on the risks of boxing? Firstly we need to reconsider the original evidence on exposure as a risk factor for CTE. The simplistic assumption based on epidemiological data from previous studies that CTE is a manifestation of the length of a boxer's career and hence exposure to punches needs to be readdressed.

Similarly the development in understanding of the genetic risk that a boxer may carry developing CTE means that this area may need to be re-examined in light of current day research. This issue also raises a number of ethical issues, if a boxer is found to be homozygous for the ApoE $\epsilon-4$ phenotype should his boxing career be curtailed? At the very least, informed consent, and genetic counseling should be undertaken.

Whilst one may argue the ethics and morality of boxing, it behooves us as scientists and clinicians to at least place the medical arguments regarding risk of injury on a scientific footing.

\section{Br J Sports Med 2002;36:2}

\section{REFERENCES}

1 Jordan B, Relkin N, Ravdin L. Apolipoprotein E epsilon 4 associated with chronic traumatic brain injury in boxing. JAMA 1997;278: 136-40.

2 Jordan B. Genetic susceptibility to brain injury in sports: A role for genetic testing in athletes? Phys Sportsmed 1998;26:25-6.

3 Jordan B, ed. Medical aspects of boxing. Boca Raton: CRC Press, 1993.

4 Nicholl J, Coleman P, Williams B. The epidemiology of sports and exercise related injury in the United Kingdom. Br J Sports Med 1995;29:232-8.

5 NH \& MRC. Boxing Injuries. Canberra: Australian Government Publishing Service, 1994.

6 Unterharnscheidt FJ. About boxing: review of historical and medical aspects. Tex Rep Biol Med 1970;28:421-95.

7 Corsellis JA, Bruton CJ, Freeman-Browne D. The aftermath of boxing. Psychol Med 1973;3:270-303.

8 Unterharnscheidt FJ. Head injury after boxing. Scand J Rehab Med 1972;4:77-84.

9 Corder E, Saunders A, Strittmatter W. Gene dose of Apolipoprotein E type 4 allele and the risk of late onset Alzheimer's disease in families. Science 1993;261:921-3.

10 Teasdale G, Nicol J, Murray G. Association of Apolipoprotein E polymorphism with outcome after head injury. Lancet 1997;350:1069-71

11 Friedman G, Froom P, Sazbon L, et al. Apolipoprotein E-epsilon 4 genotype predicts a poor outcome in survivors of traumatic brain injury. Neurology 1999;52:244-9.

12 Lomnitski L, Kohen R, Chen Y, et al. Reduced levels of antioxidants in brains of apolipoprotein E-deficient mice following closed head injury. Pharmacology, Biochemistry and Behaviour 1997;56:669-73.

Author's affiliation

P McCrory, Editor 


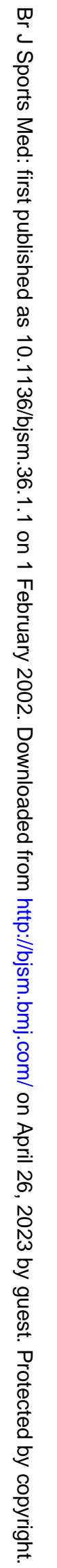




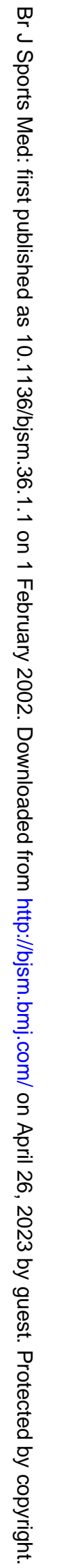




\section{EDUCATION PROGRAMME}

\section{British Association of Sport and Exercise Medicine in association with the National Sports Medicine Institute}

\section{Education programme 2002}

Intermediate Sports Injury Management and Medicine-Head, Neck, \& Upper Limb

Lilleshall National Sports Centre, 17-22 February.

General Sports Medicine

Lilleshall National Sports Centre, 21-26 April.

Diploma Preparation

Sheffield Centre of Sports Medicine, April-May.

Current Concepts: Lower Limb Rehabilitation DSMRC Headley Court, Surrey, 10-11 May .

Intermediate Sports Injury Management and Medicine-Lumbar Spine, Thorax, Groin, Pelvis, \& Hip

Lilleshall National Sports Centre, 7-12 July .

General Sports Medicine

Lilleshall National Sports Centre, 22-27 September.

Practical Sport and Medicine Meeting

Club La Santa, Lanzarote (families \& non-delegates welcome; deadline 17 July, 2002), 3-10 October.

Diploma Preparation

Location and date to be confirmed, October.
The Queen's Golden Jubilee \& Post Commonwealth Games BASEM

Congress

The Low Wood Hotel and Conference Centre, Windermere, 10-13 October.

Intermediate Sports Injury Management and Medicine-Lower Limb Lilleshall National Sports Centre, 17-22 November.

Current Concepts

Topic, location, and date to be confirmed, December.

Education programme 2003

Intermediate Sports Injury Management and Medicine-Head, Neck, and Upper Limb

Lilleshall National Sports Centre, 16-21 February.

General Sports Medicine

Lilleshall National Sports Centre, 27 April-2 May.

The Cutting Edge

Sheffield, 3-7 September

(Contact: r.m.bartlett@shu.ac.uk)

For further details of these courses please contact Mr Barry Hill, The National Sports Medicine Institute, 32 Devonshire Street, London WIG 6PX, UK. Tel: 0207486 3974; Fax:020 7935 0402; email: barry.hill@nsmi.org.uk; www.nsmi.org.uk 


\section{Expression of concern about content of which Dr Paul McCrory is a single author}

This paper is authored by Dr Paul McCrory. During 2021 and 2022 there was an investigation by BJSM and BMJ which found that some of his work was the product of publication misconduct. Such misconduct includes plagiarism, duplicate publication, misquotation and misrepresentation in publications in respect of which he was listed as the sole author. ${ }^{1}$ We are placing a notice to readers on all content in relation to which he is identified as the sole author to alert them to the conclusions of our investigation.

(C) Author(s) (or their employer(s)) 2022. No commercial re-use. See rights and permissions. Published by BMJ.

Br J Sports Med 2022;0:1. doi:10.1136/bjsports-2022-106408eoc

D) Check for updates

\section{REFERENCE}

1 Macdonald H, Ragavooloo S, Abbasi K. Update into the investigation of former BJSM editor-in-chief Paul McCrory. Br I Sports Med 2022. 